Dept. of Animal Prod., Fac. of Agric., Al-Azhar Univ., Assuit, Branch, Egypt.

\title{
SOME FACTORS AFFECTING FETAL GROWTH AND LAMB BIRTH WEIGHT IN THE RAHMANI EWES
}

(With One Table and 2 Figures)

\author{
By \\ SALEM FAHMY \\ (Received at 19/3/2009)
}

\section{بعض العوامل المؤثرة على النموالجنينى ووزن الحملان فى اغنام الرحمانى سالم فهمى محمد}

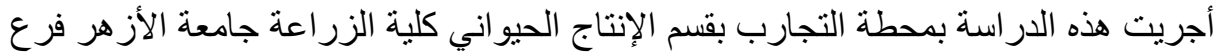

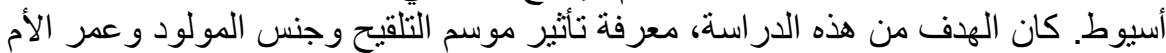

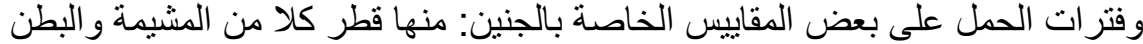

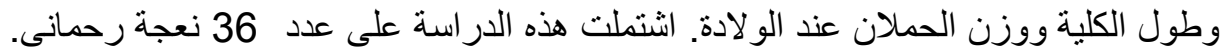

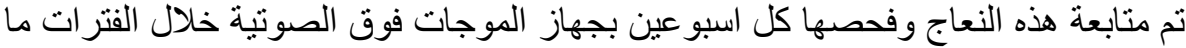

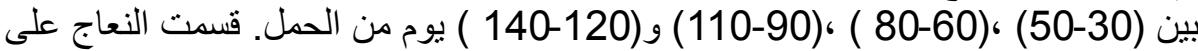

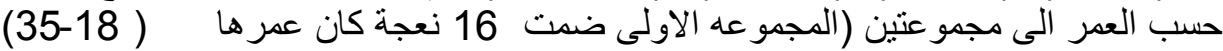

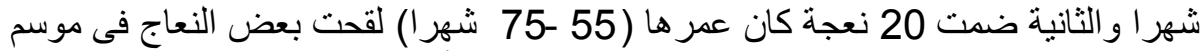

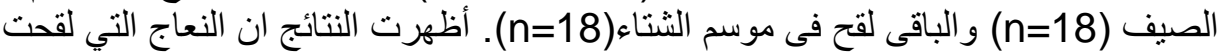

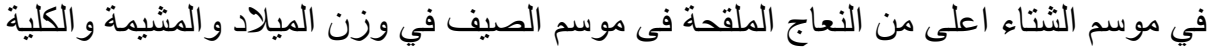

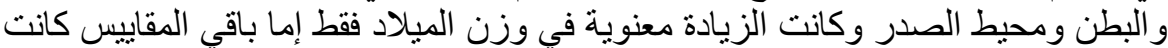

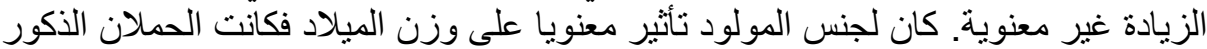

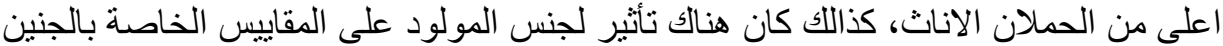

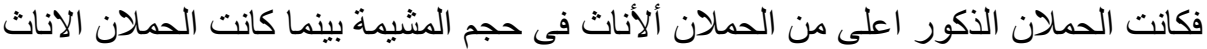

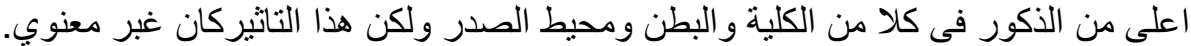

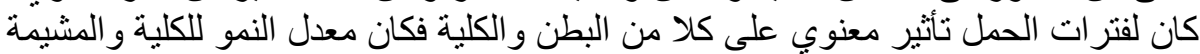

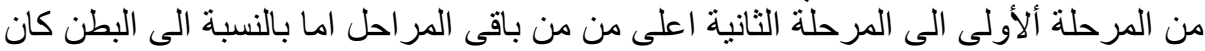

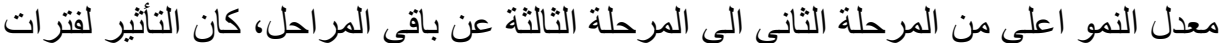

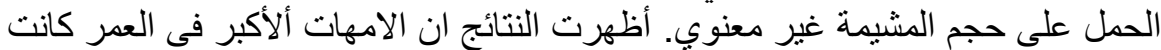

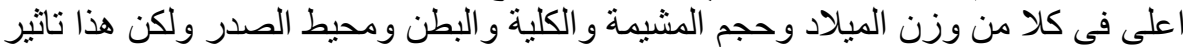

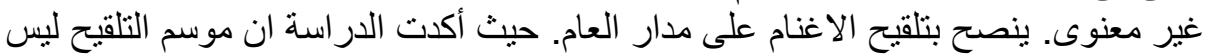

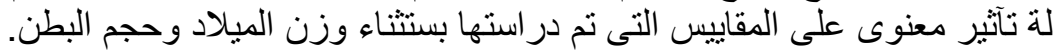


The aim of the present study was to estimate the effect of breeding season, mother age, fetal sex and gestation period on the birth weigh, placentome diameter (PLD), kidney length (KDL), chest depth (CHD) and abdominal diameter (ABD). A total of 36 ewes were included in this study, the ewes were introduced for breeding in winter and summer. Ultrasongraphic examination was done each two weeks to measure the placentome diameter, abdominal, chest depth and kidney length. The parameters were estimated at 30-50, 60-80, 90-110 and 120-140 days of gestation period. The lamb birth weight and mother birth weight were recorded just after parturition. Results showed that the male was significantly $(\mathrm{p}<0.05)$ heavier than female lambs $(3.82 \pm 0.11$ vs $3.35 \pm$ 0.07). There was no effect of the breeding season on the mean PLD, $\mathrm{CHD}, \mathrm{KDL}$ and $\mathrm{ABD}$. The mother age has no effect on lamb birth weight, PLD, CHD, KDL and ABD. The diameters of fetal kidney, placentome, abdomin and chest depth increased with gestation period. The difference was significant $(. P<0.05)$, excepted placentome diameter was non significant. There was no significant effect of fetal sex on the diameter of placentome, fetal chest depth, fetal kidney and fetal abdominal.

Conclusion: It was found that the season of breeding had no significant effected on the studied parameters, except the birth weight and abdominal diameter. So it could be advised to bred the animals all over the year

Key words: Sheep, Fetus, Development, breading, Season, Ultrasound

\section{INTRODUCTION}

The Rahmani breed is generally characterized by low litter size (average $1.14 \mathrm{~kg}$ and birth weight of the breed $3.18 \pm 0.6$ and $3.04 \pm$ $0.5 \mathrm{~kg}$ in male and female respectively). The weaning breed body weight of the average $12.62 \pm 0.28$ and $12.04 \pm 0.2 \mathrm{~kg}$ in male and female respectively, the mature body weight of this breed average $50.73 \pm 1.3$ and $35.31 \pm 0.54 \mathrm{~kg}$ male and female respectively, (Elshennawy, 1996). Ali et al. (2008) found that the lamb birth weight was affected by season, ewe age litter size and dam body weight. The combined effect of season, age and postpartum interval and ewes fertility has been described in the fall and winter and anestrous period in the spring and early summer (Lewis et al., 1996., Mitchell et al., 1999 and Chemineau et al., 2004).

Haibel (1990) consider of pregnancy diagnosis and gestation age are essential for maintenance high levels of reproductive efficiency. 
Such information would allow producers to predict parturition dates and to group animals based on their nutrition needs especially during the last trimester of pregnancy. Accessibility of the different fetal organs and parts for ultrasonic examinations depended on day of gestation. The chest depth abdominal diameter and ruminal length, could be scanned during the second trimester placentome diameter and kidney length were within the ranged of the ultrasound beam during the second trimester, (Ali and hayder, 2007).

\section{MATERIALS and METHODS}

\section{1- Animals and management}

A total of 36 clinically healthy Rahmani ewes were included in this work. The ewes were divided according to the age into two groups. The first group included 16 ewes with average age of 18-35 months and weighting $39.58 \pm 1.6 \mathrm{~kg}$. The second group included 20 ewes with average age of $55-75$ months and weighting $48.4 \pm 1.2 \mathrm{~kg}$. Before mating season, the ewes were randomly divided according to the breeding schedule in two groups. The first group were bred in July (summer, $\mathrm{n}=18$ ). The second group were bred in November (winter, $\mathrm{n}=18$ ). In each group 8 ewes were young (18-35 months) and 10 ewes were old (55-75 months) age. The ewes were bred naturally using two highly fertile Rahmani rams. The males left with the females for about two successive estrus cycles length (34 days). The animals were kept in the experimental Station of Animal Production Department of Agriculture, Al-Azhar University, Assiut Branch, Egypt. The animals were fed according to their body weight and the physiological state. All animals were fed on Egyptian clover (Trifolium alxandrinum) from December to May, while in summer season they were fed on green forage (Daraw). In addition, wheat straw and concentrated mixtures were added. The concentrated mixture consisted of $22 \%$ yellow corn, $33 \%$ wheat bran, $3 \%$ molase, $35 \%$ cotton seed meal, $4 \%$ sunflower, $2 \%$ stone and $1 \%$ salt.

\section{2- Ultrasonographic examination}

The ewes were examined ultrasonographically once each two weeks between $30^{\text {th }}$ and $140^{\text {th }}$ day of pregnancy. At the beginning of the pregnancy the ewes were examined transrectally by the advance of pregnancy the animals were examined transrectally and transabdominally. The equipment used for ultrasonography was a real time, B-mode scanner fitted with $6 / 8 \mathrm{MHz}$ linear probe. Briefly, the fecal matter was removed and the probe was introduced using probe holder into the rectum using lubricant gel. The genital tract was scanned slowly and at each scanning occasion attempts were made to the measure 
placentome diameter (PLD) Fig 1a, chest depth (CHD) Fig 1b, kidney length (KDL) and abdominal diameter (ABD).

\section{3- Statistical analysis}

The analysis was carried out according to SAS (1988). The effect of season was analyzed by ANOVA, while the effect of fetal sex was analyzed by t-test. Correlation models were fitted to evaluate the relationship between gestation age, lamb birth weight, and each of the studied parameters.

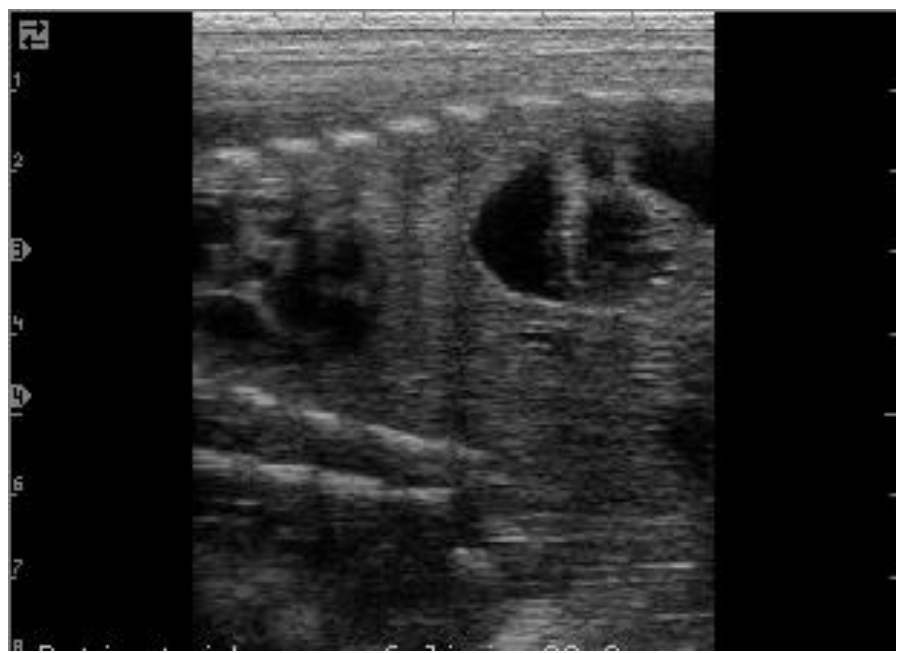

Fig 1b: Sonogram showing the chest in pregnant ewe (120 days).

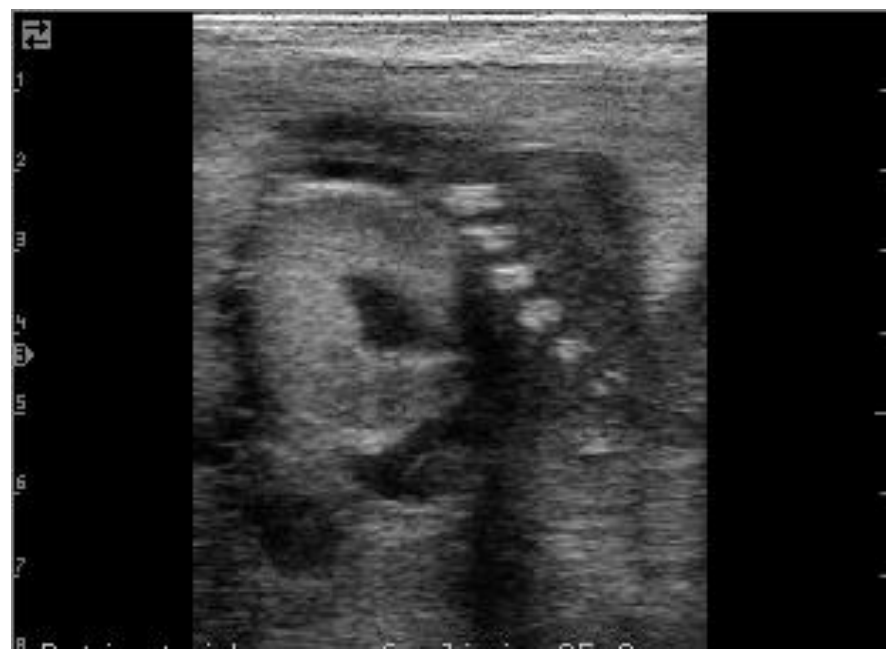

Fig 1a: Sonogram showing the placentome in pregnant ewe (80 days). RESULTS 


\section{1- Effect of breeding season:}

The weight of new born lambs which born in winter were heavier significantly $(3.89 \pm 0.16 \mathrm{~kg})$ than those born in summer breeding $(3.28 \pm 0.11 \mathrm{~kg})$. There was no effect of the breeding season on the mean placentome, fetal chest depth, kidney and abdominal diameter (Table1).

\section{2- Effect of Mother age:}

The mean placentome diameter was bigger in old ewes than younger $(2.69 \pm 0.07$ vs $2.29 \pm 0.17 \mathrm{~cm})$ but the difference was not significant. The mother age has no effect on lamb birth weight, fetal chest depth, fetal kidney and abdominal diameter (Table 1).

\section{3- Effect of gestation period:}

The placentomes increased with advanced the gestation period but the difference was not significant. The fetal chest depth increased significant $(\mathrm{P}<0.05)$ progressively with increasing of gestation period and it was $2.04 \pm 0.5 \mathrm{~cm}$ at $30-50$ days of gestation and $4.58 \pm 0.41 \mathrm{~cm}$ at 120-140 days (Fig 2).

The diameter of fetal kidney increased significantly $(. P<0.05)$ with gestation period. It was $1.62 \pm 0.21 \mathrm{~cm}$ at $30-50$ days of gestation and increased to $2.82 \pm 0.16 \mathrm{~cm}$ at $120-140$ days (Fig 2).

The fetal abdominal diameter increased significantly $(. \mathrm{P}<0.05)$ steadly with the gestation period. It was $1.56 \pm 0.32 \mathrm{~cm}$ at $30-50$ days of gestation and increased to $3.96 \pm 0.26 \mathrm{~cm}$ at $110-140$ days (Fig 2).

\section{4- Effect of fetal sex:}

Male lambs were significantly heavier than female lambs (3.82 \pm 0.1 VS. $3.35 \pm 0.07, \mathrm{P}<0.05)$. There was no significant effect of fetal sex on the diameter of placentome, fetal chest depth, fetal kidney and fetal abdominal (Table 1).

A significant positive correlation was detected between placentome diameter $(\mathrm{P}<0.05)$ at the same gestation age and the lamb birth weight $(\mathrm{r}=0.41$, and 0.56 , respectively). Also, a significant positive correlation $(\mathrm{P}<0.05)$ was detected between fetal abdominal diameter at the same gestation and the lamb birth weight $(\mathrm{r}=0.54$ and 0.40 , respectively). Added, a significant positive correlation $(\mathrm{P}<0.05)$ was detected between mother age and birth weight $(\mathrm{r}=0.041)$. There was no correlation effected between birth weight and kidney length and chest diameter

\section{DISCUSSION}


In the present study it was found that, the breeding season affects the birth weight. The new born lambs in winter were heavier than those born in summer and difference between weight significant $(\mathrm{P}<0.05)$, which those recorded by Ashmawi et al., 1984. There was no significant effect of the breeding season on the mean placentome diameter, fetal chest depth and kidney, while the effect of the season on the abdominal diameter was significant ( $\mathrm{p}<0.05)$.

The heavier birth weight in this study, in winter may be referred larger abdominal diameter, these can be assured by the significant position correlation between birth weight and abdominal diameter.

Many studies reported significant effect of season of lambing on birth weight of lams. Ali et al. (2008) found that the lamb birth weight was affected by season. The mean lamb birth weight was $3.64 \pm 0.1 \mathrm{~kg}$. It was significant heavier $(\mathrm{P}=0.001)$ for winter mating $(3.80 \pm 0.1)$ and late spring (3.83 \pm 0.1$)$ compared to fall mating season (3.39 \pm 0.1$)$. Singh et al. (1982) reported seasonal differences on lamb birth weights show autumn lambing was heavier than spring lambing in lambs.

In the present work, there was no significant effect of breeding season on the mean placentome diameter, fetal chest and kidney, while such effect was significant on the abdominal diameter $(\mathrm{P}<0.05)$. The placentome increased with increasing the gestation period but the difference was not significant. The placentome diameter tended to increase with advancing the fetal age (Fig. 1). Ali and Fahmy (2008), found that the placentome growth rate was decreased with the progress of gestation period in bufflalo. The placentome increase in size until day $82.73 \pm 7.7$, then it began to collapse. During the last month of pregnancy, it became less echogeic, while its attached surface appeared more echointensive. By this time, it started to collapse with reducing its lumen, while in areas adjacent to the fetus it appeared flattened. Collapsing of the placentome might be an indication for occurrence of a degenerative process (Grunnert, 1980; Bjorkman and Dantzer, 1987 and Ali and Hayder, 2007)). On the other hand, these changes in the placentome may be associated with increased placental perfusion and tissue permeability during late pregnancy (Metcalfe et al., 1988).

Gestation period had significant effected on kidney length, chest depth and abdominal diameter. In present study, kidney length, CHD and ABD tended to increase with advancing pregnancy. These results in agreement with the stement of Ali and Fahmy (2008). They found that the fetal ABD with increased growth rate with the progress of gestation period in bufflalo. The fetal kidney could be visualized first by day 
73.2 \pm 6.3 (range 62.-76). The echo-poor fluid rumen served as a landmark for detection of the left kidney. Early in its detection, the kidney was ill distinct, had no sharp demarcation and its echogenicity resemble to large extend that of the liver. Later on (from day 90 onwards), differentiation may be made between the renal medulla containing the more transonic discrete pyramids separated by septa (columns of Bertin) and the cortex consisting of a uniform distribution of small discrete low level echoes, (Ali and Hayder 2007).

Male lambs were significantly $(\mathrm{P}<0.05)$ heavier than female lambs $(3.82 \pm 0.11$ vs $3.35 \pm 0.07)$ in birth weight. There was no significant effect of fetal sex on the diameter of placentome, fetal chest depth, fetal kidney and fetal abdominal. The different between male and female on birth weight may be due to the different in the foetal placentome, is in agreement with results by Alexander; (1964). They found that the differences in the weight of intact cotyledons between male and female lambs were small and not consistent, total cotyledons weight was greater for male than female On the other hand, in the foetal placentome, cotyledons of male lambs were consistently heavier than those of female, so that the difference between the overall means (100 and $80 \mathrm{~g}$ ) was highly significant.

Table 1: Effect of breeding season, mother age and fetal sex on birth weight, placentome diameter, kidney length, chest depth and abdominal diameter on Rahmani ewes.

\begin{tabular}{|l|l|c|c|c|c|}
\hline \multirow{2}{*}{ Factor } & \multicolumn{5}{|c|}{ Parameters } \\
\cline { 2 - 6 } & $\begin{array}{c}\text { Birth weight } \\
\mathrm{kg}\end{array}$ & PLD & KDL & CHD & \multicolumn{1}{c|}{ ABD } \\
\hline Season winter & $3.89 \pm 0.16^{\mathrm{a}}$ & $2.68 \pm 0.09^{\mathrm{a}}$ & $2.46 \pm 0.21^{\mathrm{a}}$ & $3.46 \pm 0.18^{\mathrm{a}}$ & $3.45 \pm 0.13^{\mathrm{a}}$ \\
\hline Season summer & $3.28 \pm 0.11^{\mathrm{b}}$ & $2.34 \pm 0.18^{\mathrm{a}}$ & $2.26 \pm 0.28^{\mathrm{a}}$ & $2.74 \pm 0.45^{\mathrm{a}}$ & $2.31 \pm 0.23^{\mathrm{b}}$ \\
\hline Male & $3.82 \pm 0.1^{\mathrm{a}}$ & $2.58 \pm 0.16^{\mathrm{a}}$ & $2.35 \pm 0.26^{\mathrm{a}}$ & $3.17 \pm 0.38^{\mathrm{a}}$ & $2.46 \pm 0.33^{\mathrm{a}}$ \\
\hline Female & $3.35 \pm 0.07^{\mathrm{b}}$ & $2.45 \pm 0.19^{\mathrm{a}}$ & $2.46 \pm 0.16^{\mathrm{a}}$ & $3.28 \pm 0.3^{\mathrm{a}} 1$ & $3.7 \pm 0.42^{\mathrm{a}}$ \\
\hline Age 18-35 month & $3.57 \pm 0.26^{\mathrm{a}}$ & $2.29 \pm 0.17^{\mathrm{a}}$ & $2.36 \pm 0.24^{\mathrm{a}}$ & $3.11 \pm 0.22^{\mathrm{a}}$ & $3.312 .64 \pm 0.24^{\mathrm{a}}$ \\
\hline Age 55-70 month & $3.62 \pm 0.32^{\mathrm{a}}$ & $2.69 \pm 0.9^{\mathrm{a}}$ & $3.34 \pm 0.43^{\mathrm{a}}$ & $2.47 \pm 34^{\mathrm{a}}$ & $2.6 \pm 0.34^{\mathrm{a}}$ \\
\hline Ovaroll means & $3.58 \pm 0.07$ & $2.51 \pm 0.08$ & $3.22 \pm 0.19^{\circ}$ & $2.31 \pm 0.10$ & $2.96 \pm 0.25$ \\
\hline
\end{tabular}




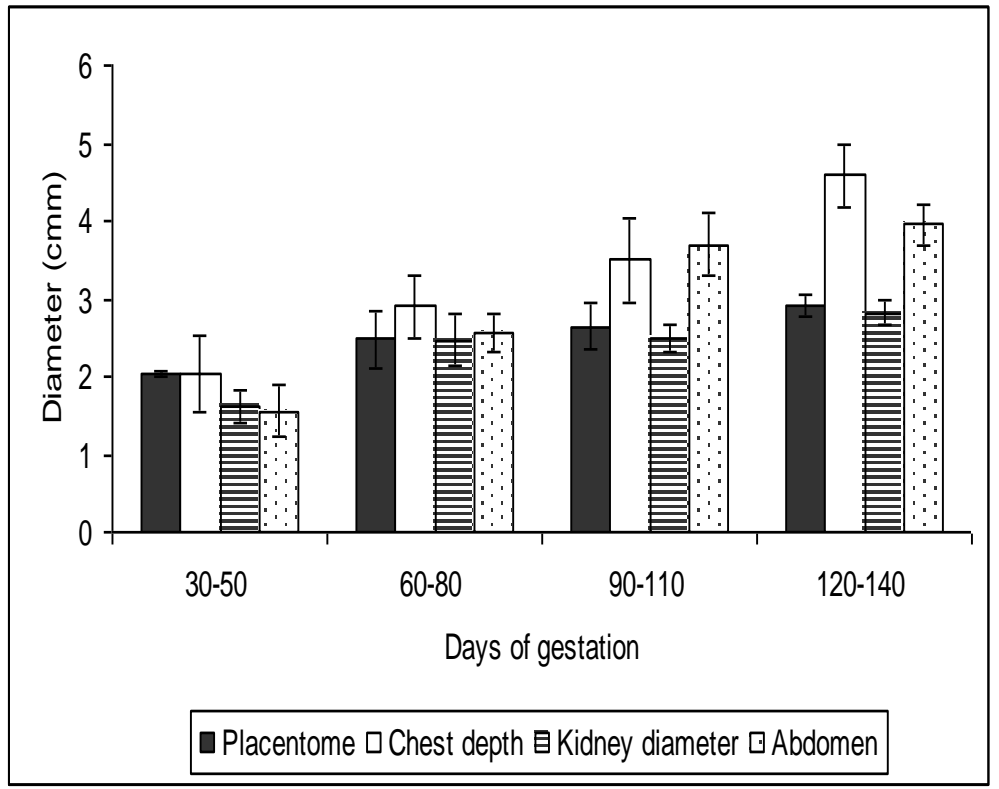

Fig. 2: Changes in the placentome diameteres, chest depth, kidney length and Abdominal diameters from 30-140 day gestation period in Rahmani ewes.

\section{REFFRENCES}

Alexander, G. (1964): Studies on the placentome of the sheep (OVIS ARIES L.). J. Reprod. Fertil, 7: 289-305.

Ali, A. and Hayder, M. (2007): Ultrasonographic assessment of embryonic, fetal and placental development in Ossimi sheep. Small Ruminant Research 73, 277-282.

Ali, A. and Fahmy, S. (2008): Ultrasonographic fetometry and determination of fetal sex in buffaloes (Bubalus bubalis). Anim. Reprod. Sci. 106: 90-99.

Ali, A.; Hayder, M. and Derar, R. (2008): Reproductive performance of Farafra ewes in the subtropics. Anim. Reprod. Sci. Press.

Ashmawi, G.M.; El-Fouly, M.; El-Talty, Y. and Salama, O. (1984):

Rahmani sheep lambing performance and post partum oesrus manifestation as affected by season of mating and type of feed. Egypt. J. Anim. Prod. 24: 119-125.

Bjorkman, N. and Dantzer, V. (1987): Placentation. In: Dellmann, H., Brown, E., (Eds.) Textbook of Veterinary Histology, $3^{\text {rd }}$ ed. Lea and Febiger, Fhiladelphia, pp. 340-359. 
Chemineau, P.; Daveau, A.; Cognie, Y.; Aumont, G. and Chesneau, D. (2004): Season ovulatory activity exists in tropical creole female goats and Black Belly ewes subjected to a temperature photoperiod. BMC physiol. 27: 4-12.

Elshennawy, M. (1996): Performance of Finn-Crossbred lambs in Egypt. Symposium on use of exotic breeds in improving sheep production Finnsheep as a case study. EGYPT, April 22-25. pp 81-88.

Grunert, E. (1980): Etiology of retained bovine placenta. In: Morrow, D.N. (Ed.). CURRENT Therapy in Theriogenology. W.B. Saunders Company. Philadellphia. pp. 180-186.

Haibel, G.K. (1990): Use of Ultrasonography in reproductive management of sheep and goat herds. Vet. Clin. North. Am. Food. Anim. Pract. 6: 597-613.

Lewis, R.M.; Notter, D.R.; Hogue, D.E. and Magee, B.H. (1996): Ewe fertility in the STAR accelerated lambing system. J. Anim. Sci. 74: 1511-1522.

Metcalfe, J.; Stock, M.K. and Barron, D.H. (1988): Maternal physiology during gestation. In: Knobile, E., Neill, J., Ewing, L.L., Green wald, G.S., Mrker, T., Pfaff, D.W. (Eds.). The Physiology of Reproduction. Ravan Press Ltd, New York, pp. 2145-2176.

Mitchell, L.M.;G.M.E., Aitken, R.P.; Gebbie, F.E. and Wallace, J.M. (1999): Ovulation, fertilization and lambing rates, and peripheral progesterone concentrations, in ewes inseminated at a natural oestrus during November or February. J.Fertil. 115: 133-140.

SAS (1988): SAS Users Guide : Statistics. SAS Inst., Cary, NC.

Singh, B.; Chopra, S.C. and Acharya, R.M. (1982): Not on factors affecting the body weights of Nali lambs, Ind. J. Anim. Sci. 52: 970-972. 